\title{
Reação de cultivares de abacateiro à podridão de raízes
}

\author{
Reaction of avocado cultivars to avocado root rot
}

Ciro Hideki Sumida ${ }^{\mathrm{I}}$ Martin Homechin ${ }^{\mathrm{II}}$ Débora Cristina Santiago ${ }^{\text {II }}$

\section{RESUMO}

As cultivares de abacateiro (Persea americana Mill) 'Margarida', 'Fortuna' $e$ 'Hass' têm muita importância econômica no mercado nacional e internacional. Em função disso, este trabalho teve como objetivo avaliar a reação dessas cultivares frente à Phytophthora cinnamomi Rands., agente causal da podridão das raízes. A inoculação do patógeno foi feita por meio de implantação de tecidos de raízes sintomáticas. Foram inoculadas quatro raízes em três árvores diferentes, uma de cada cultivar, em três pontos diferentes da raiz. Em cada cultivar, das quatro raízes, uma foi utilizada como testemunha, nas quais foram implantados tecidos sadios. A avaliação foi realizada aos 120 dias após a inoculação, observando-se as raízes externamente quanto à alteração da coloração e presença de estruturas de patógenos na região da superfície da casca nos pontos inoculados. Internamente, foram removidas as cascas para visualização das alterações a partir do ponto inoculado, sendo observadas alterações de coloração dos tecidos e realizada mensuração da extensão do escurecimento (lesão aparente). Nas extremidades das lesões foram retirados segmentos de raízes e implantados em meio de cultivo farinha de milho-ágar e incubados, para verificação da colonização na área sem escurecimento, ou seja, a colonização não- aparente. Das cultivares avaliadas, a 'Hass' foi a menos suscetível ao P. cinnamomi, quando comparada às cultivares 'Fortuna' e 'Margarida'. O patógeno $\boldsymbol{P}$. cinnamomi pode apresentar desenvolvimento ou colonização nos tecidos radiculares além da área sintomática.

Palavras-chave: Phytophthora cinnamomi, Persea americana, 'Hass', 'Fortuna', 'Margarida'.

\begin{abstract}
Cultivars of the avocado (Persea americana Mill) 'Margarida', 'Fortuna' and 'Geada' have importance in the national and international markets. The present paper had as objective to evaluate the reaction of such cultivars to Phytophthora cinanamomi Rands, the causal agent of avocado root rot. They were inoculated four roots in three different trees, one of each cultivar, in three different points of the root. In the each cultivar, from the four roots, one was used as check, where it was implanted health tissue. The evaluation was held at 120 day after inoculation, observing the roots externally, searching for color alterations and pathogen structures on the root surface region at the inoculated points. Internally, the bark was removed to visualize the alterations at the inoculated points observing alteration in the tissue color and measuring the darking extension (aparent lesion). On the lesion, segments of the root were taken and implanted on a medium of corn meal - agar, incubated to check the colonization in the area without darkness, that is, anon apparent colonization. From the evaluated cultivars, 'Hass' was the least susceptible to $\boldsymbol{P}$. cinnamomi when compared with 'Fortuna' and 'Margarida'. It was also observed that this pathogen may show development or colonization on root tissue out of the symptomatic areas.
\end{abstract}

Key words: Phytophthora cinnamomi, Persea americana, Hass, Fortuna, Margarida.

Dentre as cultivares de abacateiro (Persea americana Mill) mais comercializadas no Brasil, estão as cultivares 'Margarida' e 'Fortuna', pois possuem

'Programa de Pós-graduação em Agronomia, Departamento de Agronomia, Universidade Estadual de Londrina (UEL). Rod. Celso Garcia Cid. (PR 445), Km 380, CP 6001, 86051-990, Londrina, PR, Brasil. E-mail: cirosumida@hotmail.com. Autor para correspondência. ${ }^{\mathrm{II} D e p a r t a m e n t o ~ d e ~ A g r o n o m i a, ~ U E L, ~ L o n d r i n a, ~ P R, ~ B r a s i l . ~}$ 
características que mais se aproximam das desejadas pelo consumidor brasileiro, como frutos grandes, com peso de mais de $400 \mathrm{~g}$, casca verde e formato piriforme (CAMARGO \& MANCO, 2002). Para exportação, a cultivar 'Hass' é a mais aceita (GUIRRA NET RURAL, 2004) por ser uma cultivar diferenciada, com frutos pequenos, pesando em média 200 a $250 \mathrm{~g}$, o que garante maior valor de comercialização (FRANCISCO \& BAPTISTELLA, 2005).

O fator limitante da produção tem sido a ocorrência da podridão de raízes causada pelo patógeno Phytophthora cinnamomi Rands, considerada a doença mais destrutiva na cultura do abacateiro (PEGG et al., 2002). Nos últimos anos, esse problema tem sido muito estudado, mas nenhuma solução foi encontrada. No entanto, uma integração de medidas parece ser a única resposta para o manejo dessa doença (ERWIN \& RIBEIRO, 1996).

Devido à importância econômica das cultivares 'Margarida', 'Fortuna' e 'Hass' para o mercado nacional e internacional, e à ausência de conhecimentos do comportamento destas quanto ao patógeno $\boldsymbol{P}$. cinnamomi; o objetivo deste estudo foi avaliar a reação das cultivares em condições de campo quando inoculadas artificialmente nas raízes.

As cultivares avaliadas foram 'Fortuna', 'Margarida’ e ‘Hass’ (exportação), por meio de árvores de pé-franco e sadias, com oito anos de idade. Para inoculação, seguiu-se a metodologia descrita por MERVE et al. (1991), a qual consistiu na implantação de tecidos na região da entrecasca em raízes de árvores sadias, na profundidade de aproximadamente 10 a 40cm. Esses tecidos foram retirados de raízes sintomáticas lesionadas por $\boldsymbol{P}$. cinnamomi. Para cada cultivar, foram inoculadas quatro raízes em três árvores diferentes. Em cada raiz foram inoculados três pontos diferentes, com eqüidistância de $25 \mathrm{~cm}$ entre si. Em cada cultivar, das quatro raízes inoculadas, uma foi utilizada como testemunha, nas quais foram implantados tecidos de raízes sadios. Após a inoculação das raízes, estas foram cobertas novamente com solo.

A avaliação foi realizada aos 120 dias após a inoculação das raízes, quando foram removidas as raízes e, após a retirada do excesso de solo, analisadas externamente e internamente. Externamente foram avaliadas a alteração da coloração superficial e a presença de estruturas de patógenos nos pontos inoculados. Para avaliação da parte interna, foi realizada a remoção da casca para mensuração da área com possíveis alterações da coloração (colonização aparente). Nas extremidades das lesões, após o término do escurecimento ou a colonização aparente, foram retirados segmentos com até $5 \mathrm{~mm}$ de espessura para verificação da colonização além da área com escurecimento, ou seja, a colonização não-aparente. Foi realizada assepsia dos segmentos de raízes de $5 \mathrm{~mm}$ em álcool (70\%) por 1,0min, solução de $\mathrm{NaOCl}(0,525 \%)$ por 3,0min e água esterilizada por 1,0min; em seguida, foram implantados em meio de cultura farinha de milho (fubá) - ágar (FMA) e incubados em câmara BOD à temperatura de $24^{\circ} \mathrm{C}$ por 10 dias. Após o desenvolvimento das colônias nas placas, foi identificado o patógeno para confirmação da presença deste nas áreas com colonização não aparente. $\mathrm{O}$ delineamento experimental foi inteiramente ao acaso, com seis tratamentos e três repetições. Os dados obtidos foram submetidos à análise de variância, e as médias foram comparadas pelo teste de Scott-knott em nível de 5\% de probabilidade de erro, utilizando o programa SISVAR.

Nos resultados da avaliação externa, não foram observadas quaisquer alterações quanto à coloração, ao desenvolvimento de lesões e à presença de estruturas de patógenos. Na parte interna das raízes, após a retirada da casca, foram observadas lesões e alterações da coloração dos tecidos (colonização aparente), variando de marrom a avermelhado. $\mathrm{Na}$ cultivar 'Hass', foram observadas as menores lesões com aproximadamente 2,8cm, em comparação com as cultivares 'Fortuna' e 'Margarida', as quais apresentaram lesões maiores de 9,6cm e 9,3cm, respectivamente. Assim, com base nesses resultados, a cultivar 'Hass' pode ser considerada como menos suscetível ao patógeno. Nas raízes das testemunhas não inoculadas, foram observadas somente alterações em razão dos ferimentos do implante dos tecidos sadios, mas sem mudança na coloração dos tecidos adjacentes, característica presente nas lesões das raízes inoculadas com tecidos retirados das raízes sintomáticas.

Na avaliação da colonização "não-aparente" dos tecidos, foi detectada a presença do patógeno nos tecidos até a distância de 2,0 e 2,4cm após a área com lesão e escurecimento; entretanto, sem alteração da coloração dos tecidos. Os resultados da colonização “não-aparente” não apresentaram diferença (Tabela1), o que difere dos resultados da lesão aparente. Portanto, as três cultivares avaliadas foram suscetíveis ao $\boldsymbol{P}$. cinnamomi inoculados nas raízes. Entretanto, a cultivar 'Hass' apresentou comportamento diferente para colonização aparente.

Essas cultivares, importantes economicamente como enxertos, são pouco conhecidas quanto a sua reação ao $\boldsymbol{P}$. cinnamomi. Existem apenas trabalhos desenvolvidos por GABOR et al.(1990) com a cultivar 'Hass' sobre outros porta-enxertos como 
Tabela 1 - Avaliação do desenvolvimento da podridão de raízes nas diferentes cultivares. Cerqueira César - SP. Fazenda Jurumirim - 2006.

\begin{tabular}{ccc}
\hline Tratamentos & Colonização aparente $(\mathrm{cm})$ & Colonização não-aparente $(\mathrm{cm})$ \\
\hline MT & $2,2 \mathrm{a}$ & $\mathrm{s} / \mathrm{c}$ \\
HT & $2,1 \mathrm{a}$ & $\mathrm{s} / \mathrm{c}$ \\
FT & $2,7 \mathrm{a}$ & $\mathrm{s} / \mathrm{c}$ \\
MI & $9,3 \mathrm{~b}$ & $2,4 \mathrm{a}$ \\
HI & $2,8 \mathrm{a}$ & $2,0 \mathrm{a}$ \\
FI & $9,6 \mathrm{~b}$ & $2,4 \mathrm{a}$ \\
& & \\
CV (\%) & 32,0 & 28,7 \\
Média geral & 4,7 & 2,2 \\
\hline
\end{tabular}

MT= Testemunha Margarida; HT= Testemunha Hass; FT= Testemunha Fortuna; MI= Margarida Inoculada; HI= Hass Inoculada e FI= Fortuna Inoculada. s/c = Sem colonização.

Médias seguidas pela mesma letra não diferem entre si pelo teste Scott-knott a nível de 5\% de significância.

Thomas, Martin Grande, Barr Duke e D9, demonstrando uma maior tolerância destes à $\boldsymbol{P}$. cinnamomi. Esses dados são confirmados por resultados de MENGE et al. (1992), os quais observaram melhor desempenho dos porta-enxertos Thomas, D9 e Barr Duke em relação à Duke 7. BEN-YA'ACOV \& MICHELSON (1995) relataram que nenhum porta-enxerto é resistente ao $\boldsymbol{P}$. cinnamomi; entretanto, alguns se comportam como tolerantes devido a sua capacidade para emitir rapidamente raízes novas, de modo a repor as colonizadas e/ou destruídas pelo patógeno.

Os resultados obtidos permitem concluir que a cultivar comercial 'Hass' foi a menos suscetível a $\boldsymbol{P}$. cinnamomi, quando comparada às cultivares 'Fortuna' e 'Margarida'. Esse patógeno pode apresentar desenvolvimento ou colonização nos tecidos radiculares além da área sintomática.

\section{REFERÊNCIAS}

BEN-YA'ACOV, A.; MICHELSON, E. Avocado rootstocks. In: JANICK, J. Horticultural reviews, v.17, p.381-429, 1995.

CAMARGO, G.F; MANCO, J.R. Participação do mercado de abacate no etsp da CEAGESP em 2002. Acessado em 12 mai. 2007. Online. Disponível em: http:// www.todafruta. com.br/ todafruta.

ERWIN, D.C.; RIBEIRO, O.K. Phytophthora diseases worldwide. In: ERWIN, D.C.; RIBEIRO, O.K. Cultural and biological control. St. Paul: Minnesota: American Phytopathological Society, 1996. 592p.

FRANCISCO, V.L.F.S.; BAPTISTELLA, C.S.L. Cultura do abacate no estado de são paulo. 2005. Acessado em 21 abr. 2007. Online. Disponível em: http://www.iea.sp.gov.br

GABOR, B.K. et al. Comparison of field resistance to Phytophthora cinnamomi in twelve avocado rootstocks. Hortscience, v.25, n.12. p.1655-1656, 1990.

GUIRRA NET RURAL. (2004). Abacate. Acesso em 5 jan. 2005. Online. Disponível em: http:/www.guirra.com.br/az/ abacate.htm.

MENGE, J.A. et al. The performance of rootstocks tolerant to root rot caused by Phytophthora cinnamomi under field conditions in southern California. In: WORLD AVOCADO CONGRESS, 1987, Pretoria, South Africa. Proceedings ... Pretoria: University of Pretoria, 1987. V.1, p.53-59.

MERVE, M.V.V. et al. Evaluation of field trees for resistence to Phytophthora cinnamomi by means of the detached root technique. In: WORD AVOCADO CONGRESS 2., 1991, Riverside, California, USA. Proceedings... Riverside: University of California, Riverside and California Avocado Society, 1991. V.1, p.95-100.

PEGG K.F. et al. Foliar, fruit and soilborne diseases. In: BOTHA, A. et al. A new phosphorous acid formulation for the Effective control of Phytophthora root rot of Avocado orchards. In: WORLD AVOCADO CONGRESS 5., 2003, Granada, Málaga, Spain. Proceedings... Granada: Torremolinos Convention Center, 2003. V.1, p.567-571.

SIMÃO. S. Tratado de fruticultura. Piracicaba: FEALQ, 1998. 760p. 